\title{
PENGEMBANGAN APLIKASI SCANNER PLAGIARISME (STUDI KASUS PROPOSAL TUGAS AKHIR MAHASISWA TEKNIK INFORMATIKA UNIVERSITAS MAJALENGKA)
}

\author{
Agus Dani Awaludin Ramdani ${ }^{1}$, Deffy Susanti ${ }^{2}$ \\ ${ }^{1}$ ) Alumni Program Studi Teknik Informatika, Fakultas Teknik Universitas Majalengka \\ E-mail : \\ 2 ) Program Studi Teknik Informatika, Fakultas Teknik Universitas Majalengka \\ E-mail :deffysusanti@gmail.com
}

\begin{abstract}
The development of information technology today has the easy exchange of information not only have a positive impact but also bring negative impacts that can not be avoided that one of them is an act of plagiarism. Writers interested in develop an application that can detect plagiarism in text documents. Application plagiarism detection is performed to determine the percentage rate cribbing a document with other documents. Thus, it can be seen if a person has committed plagiarism or not. To determine whether the document contains plagiarism or not, the author uses an Smith-Watterman algorithm as a basic for counting. Smith-Waterman algorithm is an extension of string matching algorithm on text or rows as one of the dynamic program implementation. This algorithm will compare the overall length of 2 sequences were divided into sub-sections to get the highest similarity between two sequences. With the application of plagiarism scanner, compare two text documents can be done better than the manual process, documents stored comparison with relatively safe in a long time. The document that can be read or compared by application is about .txt, Microsoft office file(.dox, .docx), and pdf.
\end{abstract}

Keywords: information technology, applications, plagiarism, percentage, SmithWatterman algorithm.

\section{PENDAHULUAN}

Perkembangan dunia teknologi informasi dewasa ini menyebabkan semakin mudahnya pertukaran informasi yang tidak hanya membawa dampak yang positif tetapi juga membawa dampak negatif yang tidak dapat dihindari yaitu salah satunya adalah tindakan plagiarisme.

Plagiarisme adalah suatu tindakan menjiplak karya seseorang dan mengakuinya menjadi karyanya sendiri [NUG11]. Plagiarisme merupakan masalah yang semakin berkembang terutama dalam bidang pendidikan. Banyak karya tulis yang sebagian isinya dibuat dengan menjiplak hasil karya orang lain. Penjiplakan pada studi kasus ini difokuskan kepada karya tulis yang berbentuk dokumen teks berupa softcopy.Tindakan penjiplakan ini sangatlah buruk tidak hanya bagi karya orang yang dijiplak tetapi juga orang yang melakukan tindakan penjiplakan ini.

Dilihat dari sisi pengajar, kegiatan penjiplakan ini sangat menyusahkan dalam hal evaluasi dan penilaian. Kegiatan penjiplakan susah dideteksi bila dokumen yang diperiksa berjumlah sangat banyak dengan cara manual. Tindakan penjiplakan salah satunya terjadi di Universitas Majalengka khususnya pada pembuatan dokumen penelitian. Oleh karena itu diperlukan suatu aplikasi yang dapat digunakan untuk mendeteksi kesamaan dua buah dokumen sehingga proses pendeteksian lebih cepat [NUR13].

Aplikasi yang di buat sebelumnya tersebut belum sesuai dengan kebutuhan di Universitas Majalengka khususnya Fakultas Teknik, Berdasarkan uraian tersebut, penulis tertarik untuk mengembangkan aplikasi tersebut agar sesuai dengan kebutuhan dan proses bisnis yang berjalan, aplikasi yang dapat mendeteksi kesamaan pada dokumen teks dengan kemampuan pembacaan pada extensi pdf, doc dan docx.

Aplikasi ini dilakukan untuk mengetahui tingkat persentase kesamaan sebuah dokumen dengan dokumen lain. Sehingga, dapat diketahui apakah seseorang telah melakukan tindakan penjiplakan atau tidak [NUR13]. 
Aplikasi ini di buat menggunakan algoritma Smith-Waterman sebagai dasar perhitungan untuk membandingkan kedua dokumennya.

Algoritma Smith-Waterman merupakan perluasan algoritma pencocokan string pada teks atau barisan sebagai salah satu implementasi program dinamis. Algoritma ini akan membandingkan keseluruhan panjang 2 sekuen yang terbagi menjadi sub bagian untuk mendapatkan kesamaan tertinggi antara kedua sekuen.

\section{METODE PENELITIAN}

A. Metode Pengumpulan Data

Dalam mengumpulkan data penulis menggunakan 2 (dua) Metode yaitu :

\section{Metode Lapangan}

Metode ini di lakukan penulis secara langsung dengan mengumpulkan data yang berhubungan dengan pengolahan data instansi. Data-data tersebut penulis kumpulkan dengan cara :

a. Observasi (pengamatan langsung)

Penulis melakukan pengamatan langsung ketempat objek pembahasan yang ingin di peroleh yaitu melalui bagian prodi.

\section{b. Interview (wawancara)}

Penulis melakukan interview (wawancara) untuk mendapatkan penjelasan dari masalah-masalah yang sebelumnya kurang jelas dan untuk menyakinkan bahwa data yang diperoleh / dikumpulkan benar-benara kurat. Dimana penulis melakukan interview kepada pihak prodi.

\section{Metode Studi Pustaka}

Metode ini penulis mengutip dari beberapa bacaan yang berkaitan dengan pelaksanaan penelitian yang dilaksanakan fakultas teknik universitas majalengka.Yang di kutip dapat berupa teori ataupun beberapa pendapat dari beberapa buku bacaan dan buku diktat yang dipergunakan selama kuliah.Ini dimaksudkan untuk memberikan landasan teori yang kuat melalui bukubuku atau literatur yang tersedia di perpustakaan, baik berupa bahan-bahan kuliah dan buku pedoman yang berhubungan dengan penulisan penelitian.

\section{B. Metodologi Pengembangan Sistem}

Rapid Application Development (RAD) adalah salah satu metode pengembangan suatu sistem informasi dengan waktu yang relatif singkat. Untuk pengembangan suatu sistem informasi yang normal membutuhkan waktu minimal 180 hari, akan tetapi dengan menggunakan metode RAD suatu sistem dapat diselesaikan hanya dalam waktu 30-90 hari.

Tujuan utama dari semua metode sistem development adalah memberikan suatusistem yang dapat memenuhi harapan daripara pemakai, akan tetapi sering kali didalam melakukan pengembangan suatusistem tidak melibatkan para pemakai sistemsecara langsung, sehingga hal ini menyebabkansistem informasi yang dibuat jauhdari harapan pemakai yang dapat berakibatsistem tersebut walaupun dapat diterimatetapi para pemakai enggan untuk menggunakannyaatau bahkan para pemakaimenolak untuk menggunakannya.

\section{HASIL DAN PEMBAHASAN}

\section{A. Hasil Penelitian}

Berikut ini penulis paparkan hasil penelitian yang penulis lakukan :

\section{Fungsi Manual}

Pada gambar dibawah dapat dilihat alur kerja sistem yang masih manual yang akan dilakukan oleh reviewer, dan dapat diperkirakan akan memakan waktu yang lama untuk memdingkan dokumen yang satu dengan yang lainnya. Selain itu hasil yang diperoleh belum tentu akurat, karena hasil perbandingan yang didapat hanya perkiraan saja dan tanpa menggunakan metode tertentu, dapat dilihat pada gambar 3.1 .

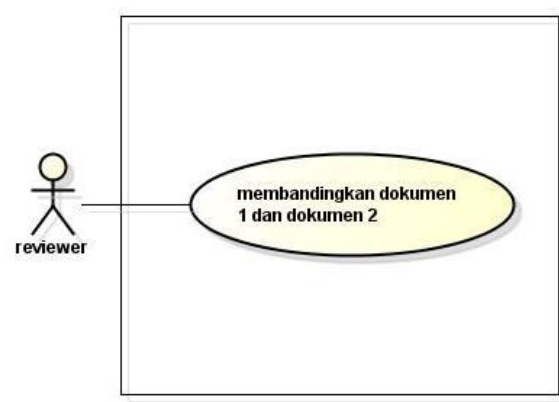


Gambar 3.1 Use Case Diagram Proses Scanner Manual

Pada proses manual ini aktifitas scanner di mulai dari membaca dokumen satu, lalu membaca dokumen dua, lalu membandingkan kedua dokumen tersebut yang di duga memiliki muatan plagiarisme setelah itu memperkirakan hasil plagiarisme tersebut, secara visual dapat di gambarkan seperti pada gambar 3.2.

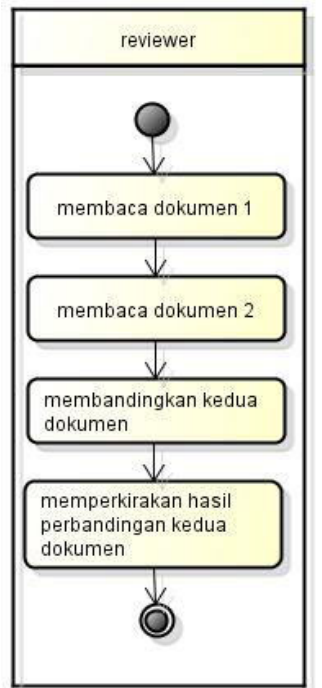

Gambar 3.2.Activity Diagram Proses

Scanner Manual

\section{Fungsi Scanner Plagiarisme}

Dokumen merupakan data yang diuji dalam sistem ini adalah berupa dokumen teks dengan membandingkan hasil kesamaan. Dengan adanya aplikasi ini pengguna tidak perlu membaca dan berusaha membandingkan dokumen, karena semua itu akan dilakukan oleh aplikasi ini, pengguna cukup memasukkan dokumen yang akan dibandingkan dan langsung dapat melihat hasil perbandingan, dapat dilihat pada gambar 3.3.

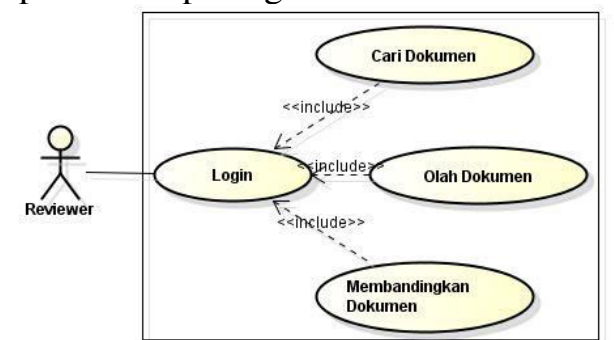

Gambar 3.3Use Case Diagram Sistem Usulan
Berikut ini keterangan dari tiap-tiap case seperti di gambakan pada tabel 3.1

Tabel 3.1 Keterangan Case

\begin{tabular}{|l|l|l|}
\hline No. & \multicolumn{1}{|c|}{ Case } & \multicolumn{1}{|c|}{ Keterangan } \\
\hline 1 & Login & $\begin{array}{l}\text { sebelum melakukan segalah } \\
\text { hal dalam system tersebut } \\
\text { Reviewer harus login terlebih } \\
\text { dahulu. }\end{array}$ \\
\hline 2 & Cari Dokumen & $\begin{array}{l}\text { Reviewer mencari dokumen } \\
\text { teks yang akan dijadikan } \\
\text { dokumen pembanding } \\
\text { berdasarkan keyword pada } \\
\text { aplikasi der dengan }\end{array}$ \\
\hline 3 & Olah Dokumen & $\begin{array}{l}\text { Reviewermenambhakan, } \\
\text { merubah, menghapus data } \\
\text { dokumen algoritma }\end{array}$ \\
\hline 4 & $\begin{array}{l}\text { Membandingkan } \\
\text { Dokumen }\end{array}$ & $\begin{array}{l}\text { proses membandingkan } \\
\text { kesamaan dua } \\
\text { dokumen teks yang telah } \\
\text { diinputkan } \\
\text { menggunakan } \\
\text { Smith-Waterman. }\end{array}$ \\
\hline
\end{tabular}

Berikut ini adalah activity diagram sistem pada aplikasi scanner plagiarisme, seperti di gambarkan pada gambar 3.4.

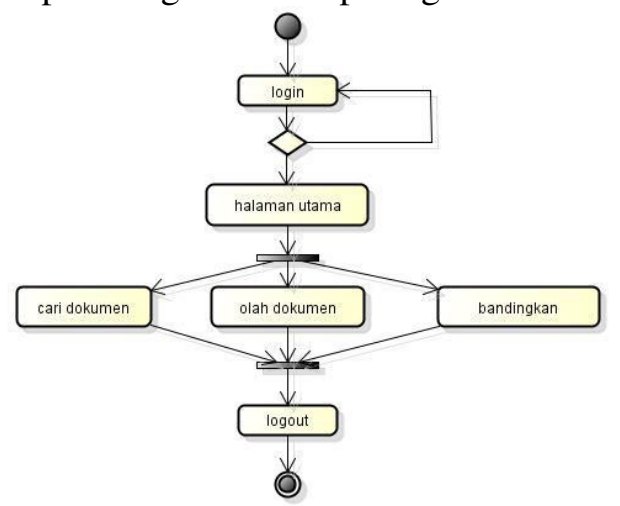

Gambar 3.4 Activity Diagram Sistem Scanner Plagiarisme

\section{Perancangan Sequence Diagram}

Perancangan Sequence Diagram betujuan untuk menggambarkan kolaborasi dinamis antar sejumlah objek. Kegunaanya untuk menunjukkan rangkaian pesan yang dikirim antara objek juga interaksi antara objek. 
Berikut ini rancangan sequence diagram pada aplikasi scanner plagiarisme

\section{1) Sequence Diagram Login Pada} Proses Login

Sequence diagram login pada proses login dapat di lihat pada gambar 3.5.

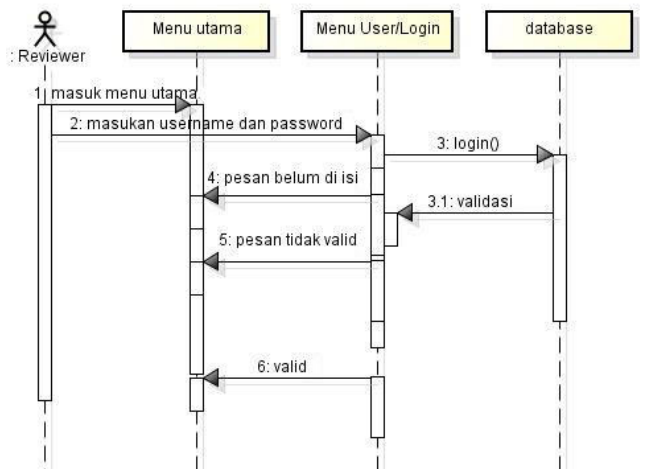

Gambar 3.5 Sequence Diagram Login Pada Proses Login

\section{2) Sequence Diagram Login Pada Proses Reset}

Sequence diagram login pada proses login dapat di lihat pada gambar 3.6.

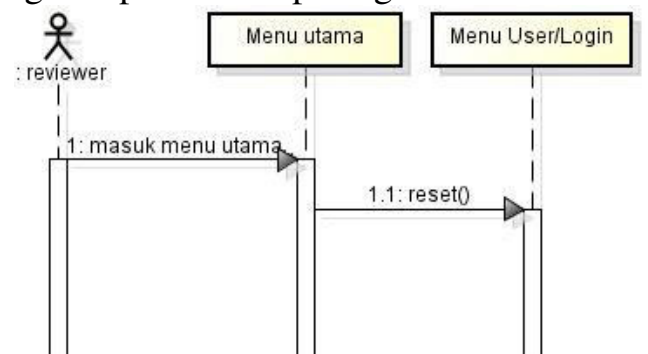

Gambar 3.6 Sequence Diagram Login Pada Proses Reset

\section{3) Sequence Diagram Olah Dokumen} Pada Proses Tambah Dokumen

Sequence diagram olah dokumen pada proses tambah dokumen dapat di lihat pada gambar 3.7.

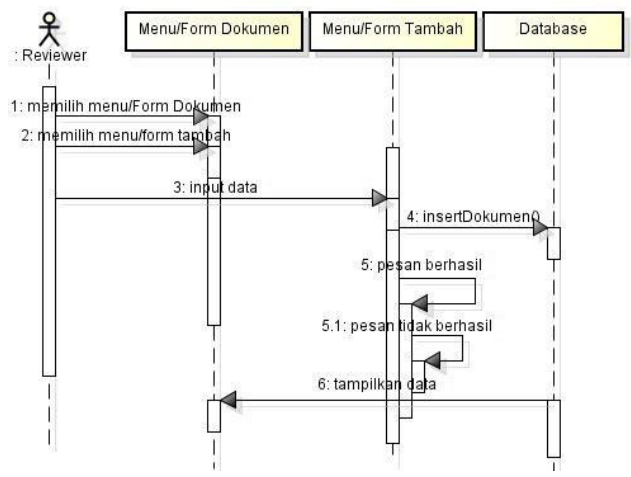

Gambar 3.7. Sequence Diagram Olah Dokumen Pada Proses Tambah Dokumen

\section{4) Sequence Diagram Olah Dokumen Pada Proses Ubah Dokumen}

Sequence diagram olah dokumen pada proses ubah dokumen dapat di lihat pada gambar 3.8.

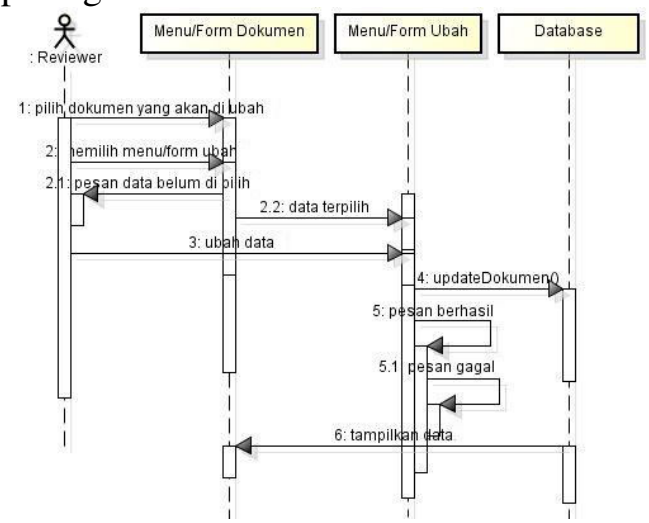

Gambar 3.8 Sequence Diagram Olah

Dokumen Pada Proses Ubah Dokumen

\section{5) Sequence Diagram Olah Dokumen Pada Proses Hapus Dokumen}

Sequence diagram olah dokumen pada proses hapus dokumen dapat di lihat pada gambar 3.9.

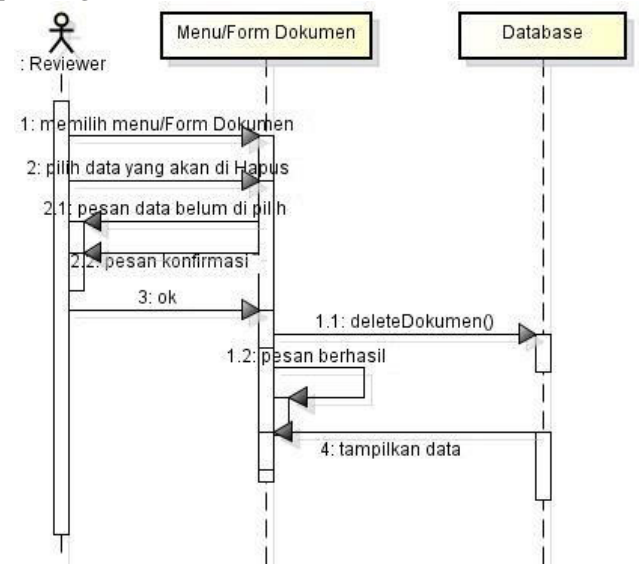

Gambar 3.9 Sequence Diagram Olah Dokumen Pada Proses Hapus Dokumen

\section{6) Sequence Diagram Membandingkan Dokumen}

Sequence Diagram membandingkan dokumen dapat di lihat pada gambar 3.10. 


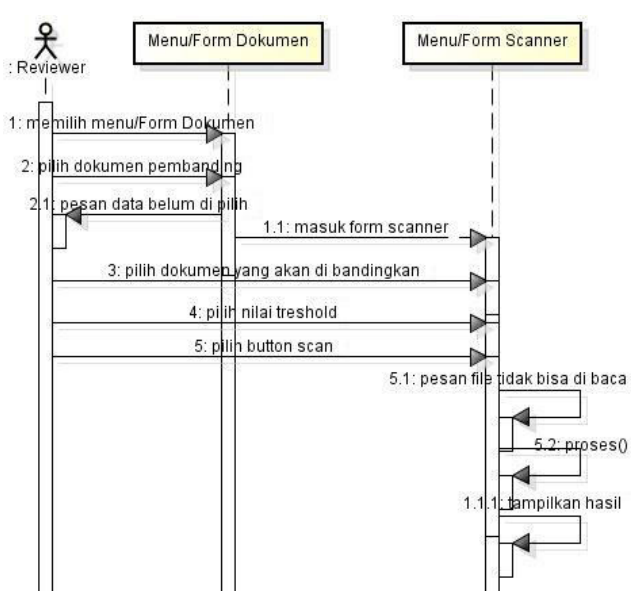

Gambar 3.10 Sequence Diagram Membandingkan Dokumen

\section{Perancangan Class Diagram}

Perancangan Class Diagram bertujuan untuk menggambarkan struktur statis class dalam sistem.

Class diagram aplikasi scanner plagiarisme dapat di gambarkan pada gambar 3.11.

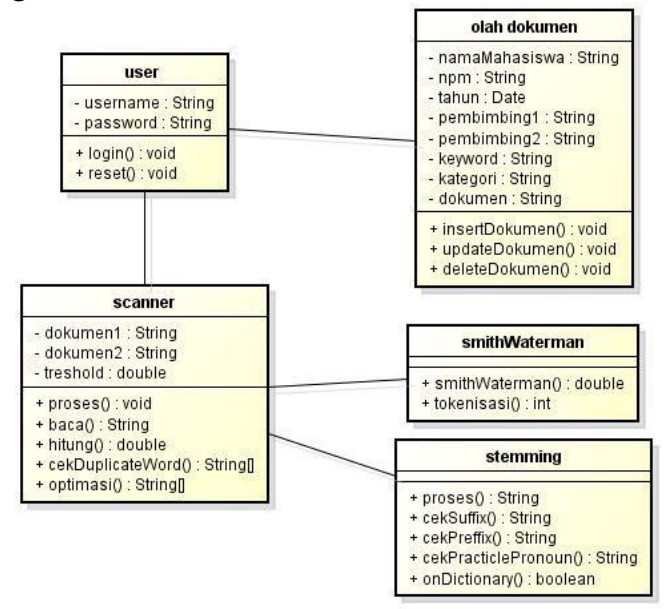

Gambar 3.11. Class Diagram

\section{Flowchart Algoritma Scannner Plagiarisme \\ Berikut ini ilustrasi flowchart dari tahapan logis di atas, di gambarkan pada gambar 3.12.}

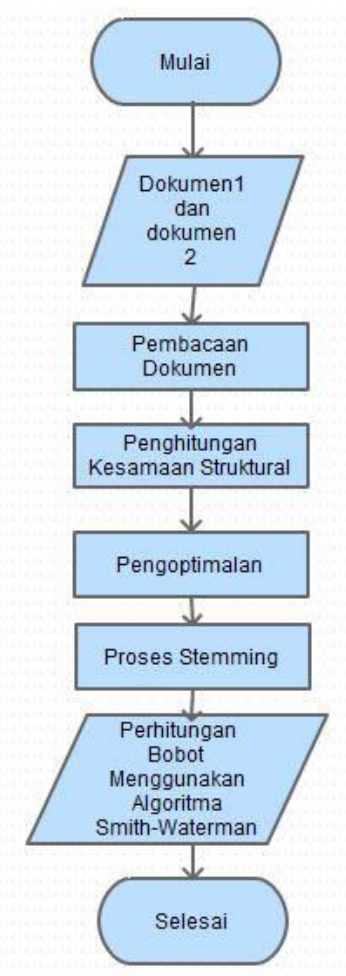

Gambar 3.12 Flowchart Algoritma Scanner

\section{Flowchart \\ Smith_Waterman}

Algoritma

Berikut ini ilustrasi flowchart dari tahapan logis di atas, di gambarkan pada gambar 3.13. 


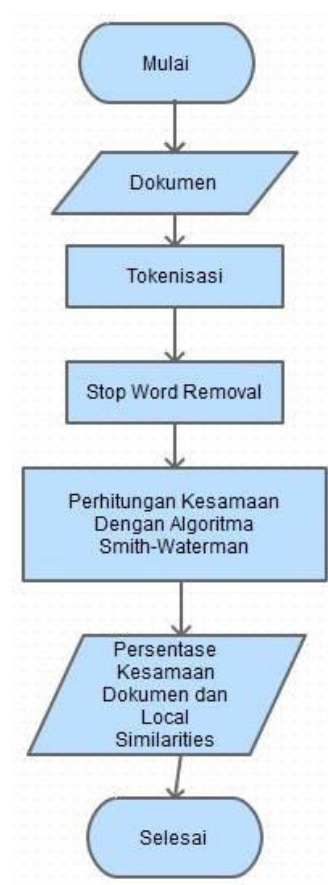

Gambar 3.13 Flowchart Algoritma SmithWaterman

\section{B. Pembahasan}

Setelah melakukan perancangan dan pembangunan perangkat lunak, kemudian tahap selanjutnya dengan mengimplementasikan antar muka (interface) dari suatu perangkat lunak agar user lebih awal mengenal tampilan suatu pernagkat lunak, berikut ini implementasi antar muka dari aplikasi scanner plagiarisme.

1) Antarmuka Login

Antarmuka Login/Form Login merupakan suatu form yang ada pada Sistem Scanner Plagiarisme yang berfungsi untuk mengautentifikasi user/pengguna yang akan menggunakan sistem/aplikasi scanner plagiarismeini, berikut ini gambaran dari form login yang di gambarkan pada gambar 3.14.

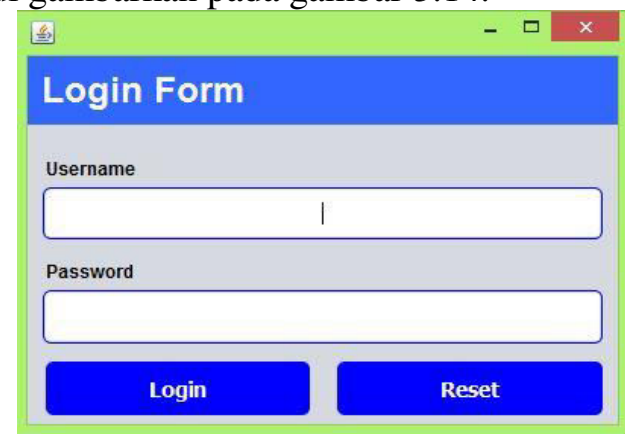

Gambar 3.14 Antarmuka Login

\section{2) Antarmuka Halaman Utama}

Berikut ini gambaran antarmuka halaman utama yang di gambarkan dalam gambar 3.15.

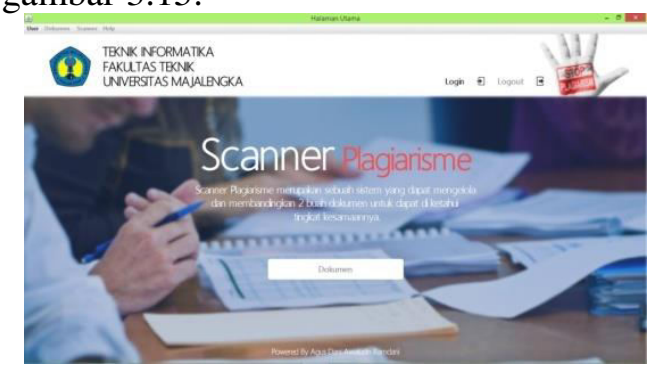

Gambar 3.15 Antarmuka Halaman Utama

\section{3) Antarmuka Dokumen}

Antarmuka dokumen/form dokumen merupakan form yang berfungsi untuk mengolah dokumen, beberapa aktifitas yang dapat di lakukan di form tersebut di antaranya yaitu mencari dokumen berdasarkan keyword, menabahkan dokumen, mengubah dokumen, menghapus dokumen, dan membandingkan dokumen. Berikut ini gambaran antarmuka dokumen tersebut yang di gambarkan dalam gambar 3.16.

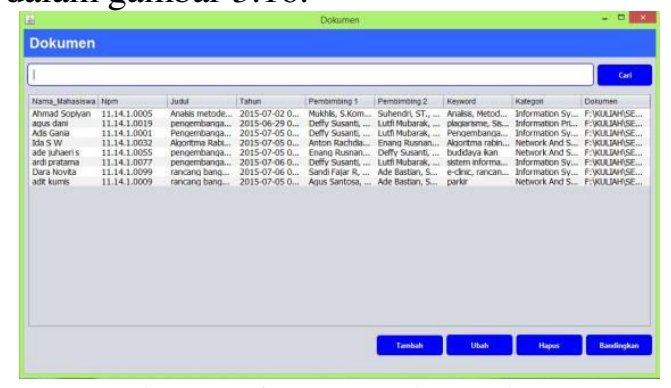

Gambar 3.16 Antarmuka Dokumen

\section{4) Antarmuka Tambah Dokumen}

Antarmuka tambah dokumen/form tambah dokumen merupakan form yang berfungsi untuk menambahkan dokumen, berikut ini gambaran dari antarmuka tersebut yang di gambarkan dalam gambar 3.17 . 


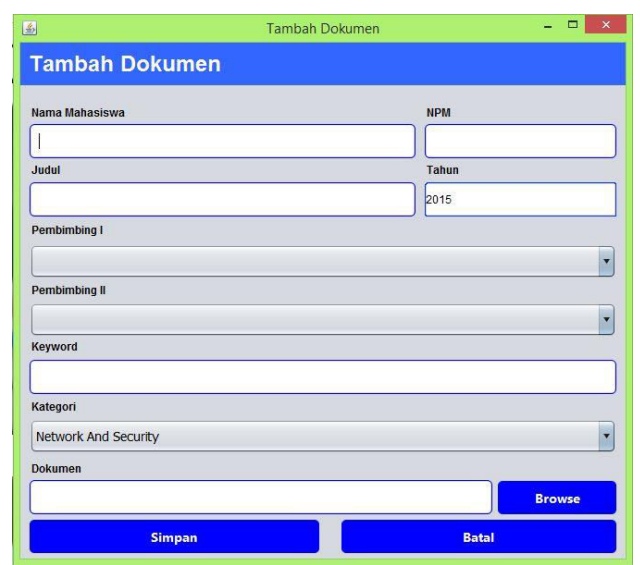

Gambar 3.17 Antarmuka Tambah Dokumen

\section{5) Antarmuka Ubah Dokumen}

Antarmuka ubah dokumen/form ubah dokumen merupakan form yang berfungsi untuk mengubah dokumen, berikut ini gambaran dari antarmuka tersebut yang di gambarkan dalam gambar 3.18.

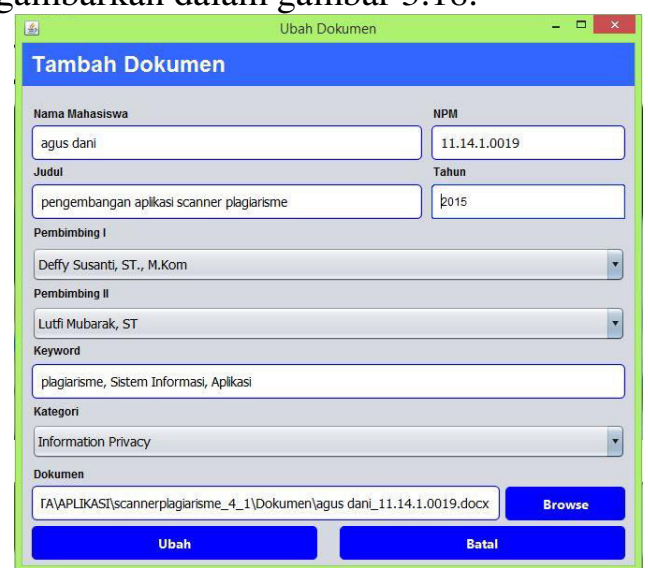

Gambar 3.18 Antarmuka Ubah Dokumen

\section{6) Antarmuka Scanner}

Antarmuka scanner/form scanner merupakan form yang berfungsi untuk membandingkan kedua dokumen, berikut ini gambaran dari antarmuka tersebut yang di gambarkan dalam gambar 3.19.

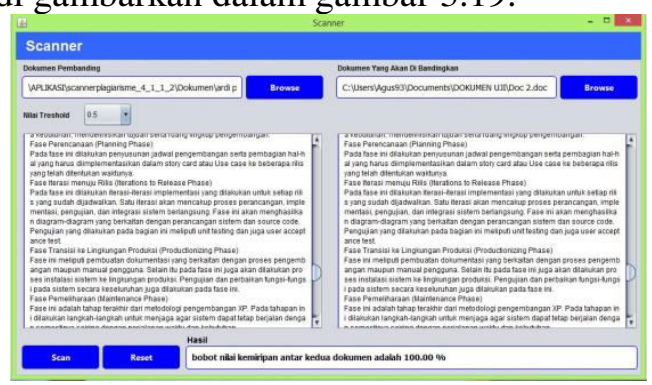

Gambar 3.19 Antarmuka Scanner

\section{7) Antarmuka About}

Antarmuka about/form about merupakan form yang berfungsi untuk menampilkan informasi dari sistem tersebut. Berikut ini gambaran dari antararmuka tersebut yang di gambarkan dalam gambar 3.20.

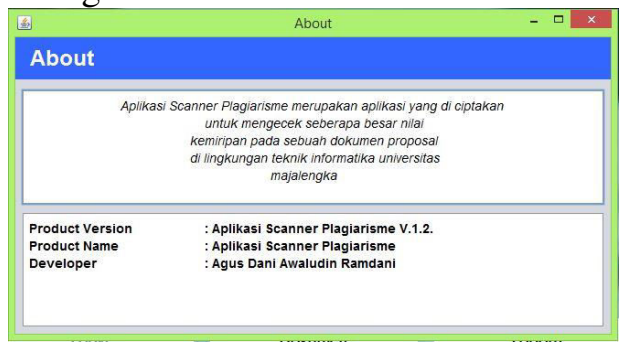

Gambar 3.20 Antarmuka About

Setelah melakukan implementasi, selanjutnya kita akan lakukan pengujian terhadap program tersebut, Pengujian dilakukan dengan metode black-box. Pengujian ini lebih menekankan kepada respon dari sistem terhadap perintah yang diberikan. Dilihat dari (output) tampilan/pesan yang dimunculkan, apakah sesuai dengan perancangan atau tidak. Pengujian black box ini terbagi dalam 2 bagaian, yaitu pengujian sistem secara keseluruhan dan pengujian sistem scanner secara detail

Adapun untuk hasil dari pengujian sistem secara keseluruhandapat di lihat pada table 3.2.

Tabel 3.2 pengujian blackbox

\begin{tabular}{|l|l|l|}
\hline $\begin{array}{c}\text { Fungsi } \\
\text { yang di } \\
\text { uji }\end{array}$ & Cara pengujian & Hasil yang di harapkan \\
\hline $\begin{array}{l}\text { Form } \\
\text { Login }\end{array}$ & $\begin{array}{l}\text { Pada form login } \\
\text { user di minta } \\
\text { memasukan } \\
\text { username dan }\end{array}$ & $\begin{array}{l}\text { Hasilnya dengan username } \\
\text { dan password bernar } \\
\text { berhasil masuk form utama } \\
\text { dengan fungsi menu-menu }\end{array}$ \\
\hline & $\begin{array}{l}\text { password, kami } \\
\text { uji dengan } \\
\text { memasukan } \\
\text { username dantif, dan ketika username } \\
\text { password password salah user } \\
\text { benar, dan } \\
\text { username dan } \\
\text { tidak bisa masuk ke sistem } \\
\text { password salah. } \\
\text { pesan }\end{array}$ \\
\hline
\end{tabular}




\begin{tabular}{|c|c|c|}
\hline $\begin{array}{l}\text { Halaman } \\
\text { Utama }\end{array}$ & $\begin{array}{lr}\text { Masuk } & \text { ke } \\
\text { halaman } & \text { utama }\end{array}$ & Masuk ke halaman utama \\
\hline \multirow[t]{2}{*}{ Dokumen } & $\begin{array}{lr}\text { Padar } & \text { form } \\
\text { dokumen } & \text { user } \\
\text { di } & \text { minta } \\
\text { melakukan } \\
\text { aktfitas: } \\
\text { 1. } \\
\text { 1. Pencarian } \\
\text { 2. } & \text { Pemambah } \\
\text { an } \\
\text { 3. } & \text { Pengubaha } \\
& n \\
\text { 4. } & \text { Penghapusa } \\
& n \\
\text { 5. } & \text { Pembanding } \\
\text { an }\end{array}$ & $\begin{array}{l}\text { Hasilnya : } \\
\text { 1. pada proses pencarian } \\
\text { ketika data di temukan } \\
\text { maka di tampilkan ke } \\
\text { tabel, jika data tidak di } \\
\text { temukan tabel kosong } \\
\text { 2. padar proses } \\
\text { penambahan akan } \\
\text { menapilkan form } \\
\text { tambah proses } \\
\text { 3. pada da dan } \\
\text { pengubahan, jika data } \\
\text { yang akan di ubah } \\
\text { telah di kirim ke form } \\
\text { ubah, jika data belum } \\
\text { di pilih maka akan di } \\
\text { tampilkan pesan } \\
\text { 4. pada proses } \\
\text { penghapusan jika data } \\
\text { telah di pilih maka }\end{array}$ \\
\hline & & $\begin{array}{l}\text { akan di tampilkan } \\
\text { pesan konfirmasi dan } \\
\text { jika ya maka sistem } \\
\text { akan melakukan } \\
\text { penghapusan, jika data } \\
\text { belum di pilih maka } \\
\text { akan di tampilkan } \\
\text { pesan } \\
\text { 5. pada proses } \\
\text { pembandingkan, jika } \\
\text { data telah di pilih maka } \\
\text { akan di kirim ke form } \\
\text { scan, jika data belum di } \\
\text { pilih maka akan di } \\
\text { tampilkan pesan }\end{array}$ \\
\hline \begin{tabular}{|l|} 
Tambah \\
Dokumen
\end{tabular} & $\begin{array}{l}\text { Pada form } \\
\text { tambah } \\
\text { dokumen user } \\
\text { di minta untuk } \\
\text { menginputkan } \\
\text { data-data } \\
\text { dengan benar, } \\
\text { dan data-data } \\
\text { dengan salah }\end{array}$ & $\begin{array}{l}\text { Hasilnya, } \\
\text { menginputkan dengan } \\
\text { dengan benar sistem } \\
\text { berhasil menyimpan data, } \\
\text { dengan menginputkan } \\
\text { data-data tidak bernar } \\
\text { sistem akan menampilkan } \\
\text { pesan }\end{array}$ \\
\hline \begin{tabular}{|l|} 
Ubah \\
Dokumen
\end{tabular} & $\begin{array}{l}\text { Pada form ubah } \\
\text { dokumen user } \\
\text { di minta untuk } \\
\text { ubah data-data } \\
\text { dengan benar, } \\
\text { dan data-data } \\
\text { dengan salah }\end{array}$ & $\begin{array}{l}\text { Hasilnya, dengan ubah } \\
\text { data-data dengan benar } \\
\text { sistem berhasil menyimpan } \\
\text { data, dengan ubah data- } \\
\text { data tidak bernar sistem } \\
\text { akan menampilkan pesan }\end{array}$ \\
\hline
\end{tabular}

\begin{tabular}{|c|c|c|}
\hline Scanner & 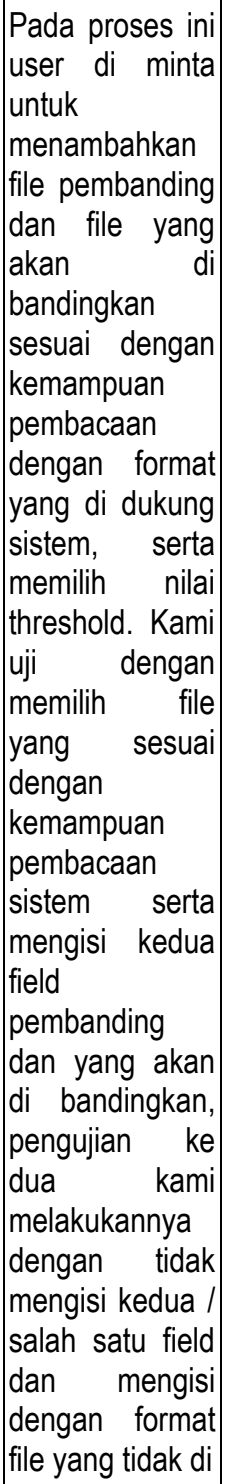 & 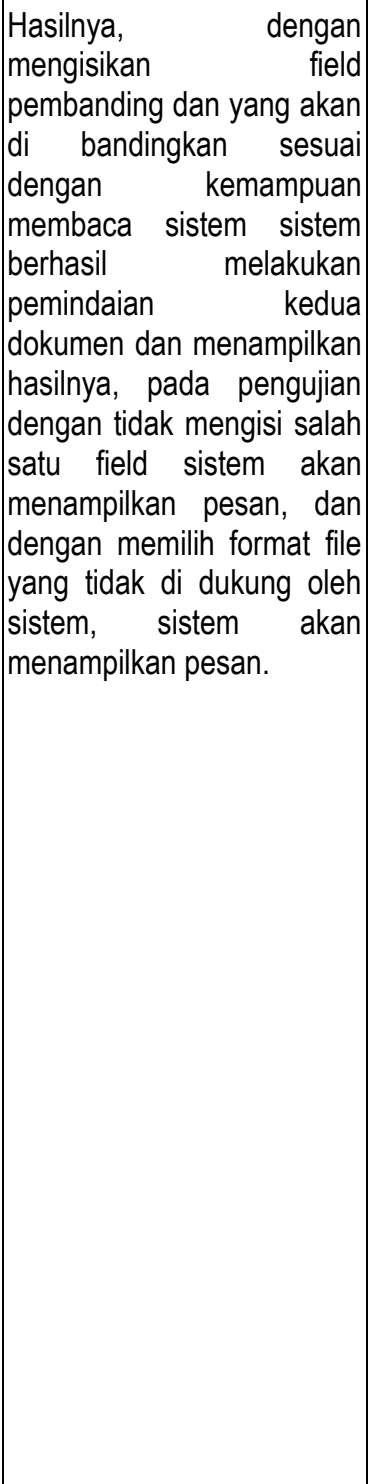 \\
\hline \multirow[t]{2}{*}{$\begin{array}{c}\text { Fungsi } \\
\text { yang di } \\
\text { uji }\end{array}$} & Cara pengujian & Hasil yang di harapkan \\
\hline & $\begin{array}{l}\text { dukung oleh } \\
\text { sistem }\end{array}$ & \\
\hline About & $\begin{array}{l}\text { Memilih form } \\
\text { about }\end{array}$ & $\begin{array}{l}\text { Hasilnya menampilkan form } \\
\text { about }\end{array}$ \\
\hline Logout & $\begin{array}{ll}\text { Memilih } & \text { menu } \\
\text { atau } & \text { button } \\
\text { logout } & \\
\end{array}$ & Hasilnya keluar dari sistem \\
\hline
\end{tabular}

Dan untuk pengujian scanner plagiarisme di lakukan dengan menguji sampel dokumen proposal penelitian mahasiswa yang mengajukan penelitian tahun 2015 yang telah di modifikasi sedemikian rupa hingga memiliki beberapa kesamaan, berikut ini sampel yang akan di uji, dapat di lihat pada tabel 3.3. 
Tabel 3.3 Sampel Dokumen Yang Akan Di Uji

\begin{tabular}{|c|c|}
\hline \begin{tabular}{|c|} 
Nama \\
Dokumen
\end{tabular} & Keterang \\
\hline Dok 1.txt & $\begin{array}{l}\text { Merupakan dokumen proposal milik Ahmad } \\
\text { Imron yang telah di modifikasi sedemikian } \\
\text { rupa untuk keperluan pengujian hingga } \\
\text { memiliki beberapa kesamaan dengan } \\
\text { dokumen lain. }\end{array}$ \\
\hline Dok 2.doc & $\begin{array}{l}\text { Merupakan dokumen proposal milik Ardi } \\
\text { Pratama yang telah di modifikasi sedemikian } \\
\text { rupa untuk keperluan pengujian hingga } \\
\text { memiliki beberapa kesamaan dengan } \\
\text { dokumen lain. }\end{array}$ \\
\hline \begin{tabular}{|l} 
Dok \\
3.docx
\end{tabular} & $\begin{array}{l}\text { Merupakan dokumen proposal milik Eva } \\
\text { Fibriani yang telah di modifikasi sedemikian } \\
\text { rupa untuk keperluan pengujian hingga } \\
\text { memiliki beberapa kesamaan dengan } \\
\text { dokumen lain. }\end{array}$ \\
\hline Dok 4.pdf & $\begin{array}{l}\text { Merupakan dokumen proposal milik Harun } \\
\text { Ramadhanto yang telah di modifikasi } \\
\text { sedemikian rupa untuk keperluan pengujian } \\
\text { hingga memiliki beberapa kesamaan } \\
\text { dengan lain. }\end{array}$ \\
\hline
\end{tabular}

Hasil dari pengujian scanner plagiarisme tersebutdapat di lihat pada table $3.4,3.5,3.6$

Tabel 3.4 Hasil Pengujian Dengan Nilai Treshold 0.3

\begin{tabular}{|c|c|c|c|c|}
\hline \multicolumn{5}{|c|}{ Pengujian Dengan Nilai Treshold 0.3 } \\
\hline $\begin{array}{c}\text { Dokumen } \\
\text { Yang Di Uji }\end{array}$ & $\begin{array}{c}\text { Dok } \\
1 . t x t \\
\%\end{array}$ & $\begin{array}{c}\text { Dok } \\
2 . d o c\end{array}$ & $\begin{array}{c}\text { Doc } \\
3 . d o c x\end{array}$ & $\begin{array}{c}\text { Doc } \\
4 . p d f \\
\%\end{array}$ \\
$\%$ \\
\hline Doc 1.txt & 98,71 & 47,02 & 30,56 & 0 \\
\hline Doc 2.doc & 56,91 & 98,88 & 30,00 & 0 \\
\hline Doc 3.docx & 32,05 & 30,00 & 100 & 0 \\
\hline Doc 4.docx & 0 & 0 & 0 & 100 \\
\hline
\end{tabular}

Dari tabel tersebut dengan nilai threshold 0.3 terlihat bahwa nilai threshold mempengaruhi terhadap persentase kesamaan kedua dokumen, dapat di lihat pada pengujian doc 1.txt dan doc 1.txt, dan doc 2.doc dan doc 2.doc. dan bila hasil perhitungan kesamaan struktural lebih kecil atau sama dengan nilai threshold maka dinilai kedua dokumen tidak sama.

Tabel 3.5 Hasil Pengujian Dengan Nilai Treshold 0.5

\begin{tabular}{|c|c|c|c|c|}
\hline \multicolumn{5}{|c|}{ Pengujian Dengan Nilai Treshold 0.5} \\
\hline $\begin{array}{c}\text { Dokumen } \\
\text { Yang Di Uji }\end{array}$ & $\begin{array}{c}\text { Dok } \\
\text { 1.txt } \\
\\
\%\end{array}$ & $\begin{array}{c}\text { Dok } \\
\text { 2.doc } \\
\%\end{array}$ & $\begin{array}{c}\text { Doc } \\
\text { 3.docx } \\
\%\end{array}$ & $\begin{array}{c}\text { Doc } \\
\text { 4.pdf } \\
\%\end{array}$ \\
\hline Doc 1.txt & 100 & 0 & 0 & 0 \\
\hline Doc 2.doc & 0 & 100 & 0 & 0 \\
\hline Doc 3.docx & 0 & 0 & 100 & 0 \\
\hline Doc 4.docx & 0 & 0 & 0 & 100 \\
\hline
\end{tabular}

Dari tabel tersebut dengan nilai threshold 0.5 terlihat bahwa nilai threshold mempengaruhi terhadap persentase kesamaan kedua dokumen, bila kita lihat pada tabel 5.10 maka terlihat perbedaannya.dan bila hasil perhitungan kesamaan struktural lebih kecil atau sama dengan nilai threshold maka dinilai kedua dokumen tidak sama.

Tabel 3.6 Hasil Pengujian Dengan Nilai Treshold 0.8

\begin{tabular}{|c|c|c|c|c|}
\hline \multicolumn{5}{|c|}{ Pengujian Dengan Nilai Treshold 0.8} \\
\hline Dokumen & Dok & Dok & Doc & Doc \\
Yang Di Uji & $1 . t x t$ & $2 . d o c$ & $3 . d o c x$ & $4 . p d f$ \\
$\%$ & $\%$ & $\%$ & $\%$ \\
\hline Doc 1.txt & 100 & 0 & 0 & 0 \\
\hline Doc 2.doc & 0 & 100 & 0 & 0 \\
\hline
\end{tabular}




\begin{tabular}{|c|c|c|c|c|}
\hline Doc 3.docx & 0 & 0 & 100 & 0 \\
\hline Doc 4.docx & 0 & 0 & 0 & 100 \\
\hline
\end{tabular}

Dari tabel tersebut dengan nilai threshold 0.8 terlihat bahwa nilai threshold mempengaruhi terhadap persentase kesamaan kedua dokumen, bila kita lihat pada tabel 5.10 maka terlihat perbedaannya.dan bila hasil perhitungan kesamaan struktural lebih kecil atau sama dengan nilai threshold maka dinilai kedua dokumen tidak sama.

\section{KESIMPULAN}

Berdasarkan hasil analisis serta perancangan yang telah di lakukan maka dapat penulis tarik kesimpulanya sebagai berikut :

1. Aplikasi ini mampu membaca dokumen teks dalam format .pdf, .doc, .docx, .txt, untuk membaca format tersebut penulis menggunakan teknik parsing.

2. Proses penghitungan kedua dokumen menggunakan algoritma Smith-Watterman. 3. Pada proses stemming semakin banyak kata dasar yang di miliki maka semakin lama proses scanningnya.

4. Nilai ambang batas/threshold sangat mempengaruhi hasil persentase pembandingan kedua dokumen.

\section{REFERENSI}

Ernawati. Puspitaningrum, D. Pravitasari, A. 2014. Implementasi Algoritma SmithWatterman Pada Local Alignment Dalam Pencarian Kesamaan Pensejajaran Barisan DNA(Studi Kasus : DNA Tumor Wilms). Jurnal Pseudecode. 1(2):170177.

Farid B.D. 2014. Penerapan Algoritma SmithWatterman Dalam Sistem Pendeteksi Kesamaan Dokumen. Penelitian. Fakultas Teknik Universitas Negri Gorontalo, Gorontalo.

Farid T, Ratih K. 2014. Pembuatan Program Aplikasi Untuk Pendeteksi Kemiripan Dokumen Teks dengan Algoritma SmithWatterman.
Ikhwan, Aris. "Langkah RUP”, 21 November 2013 http://arisikhwan.files.wordpress.com, 2009.

Ikhwan, Arief."Pengertian UML", 21 November 2013 , http://ariefikhwan.web.ugm.ac.id, 2012.

Novanta, A. 2009. Pendeteksian Plagiarisme Dokumen Teksdengan Menggunakan Algoritma Smith-Waterman. Penelitian. Fakultas Matematika Dan Ilmu Pengetahuan Alam Universitas Sumatra Utara, Medan. 